\title{
ECONOMIC FEASIBILITY OF ANAEROBIC DIGESTION WITH SWINE OPERATIONS
}

\author{
CORTNEY A. COWLEY \\ Department of Agricultural Economics, Oklahoma State University, Stillwater, Oklaboma; \\ Present address: Federal Reserve Bank of Kansas City, Omaha, Nebraska \\ B. WADE BRORSEN* \\ Department of Agricultural Economics, Oklahoma State University, Stillwater, Oklaboma \\ DOUGLAS W. HAMILTON \\ Department of Biosystems and Agricultural Engineering, Oklahoma State University, Stillwater, Oklahoma
}

\begin{abstract}
Anaerobic digestion systems can reduce greenhouse gas emissions while turning waste products into energy. Past U.S. economic research on anaerobic digesters has studied dairy farms, but limited economic information is available on anaerobic digestion systems for swine. Net present values (NPVs) were calculated for biodigesters and covered lagoons under different coproduct and policy scenarios. With no government intervention, covered lagoons are more promising for swine operations than more capital-intensive biodigesters. As there is interest in subsidizing anaerobic digestion systems, subsidies equal to a $\$ 38 / \mathrm{t}$ social cost of carbon would provide positive NPVs.
\end{abstract}

Key words. Anaerobic digestion, biodigesters, coproduct marketing, covered lagoon, greenhouse gas emissions, renewable energy policy, swine manure

JEL Classifications. H23, Q42

\section{Introduction}

As animal production facilities become larger and more concentrated, the risk of environmental externalities increases (Centner, 2003). Environmental degradation from nutrient pollution, specifically phosphorus, consistently ranks as one of the top water quality issues, and Carpenter et al. (1998) found that phosphorus pollution was directly related to livestock stocking rates upstream. In addition to water quality impairments, the livestock industry is

The views expressed are those of the authors and do not necessarily reflect the positions of the Federal Reserve Bank of Kansas City or the Federal Reserve System. The authors would like to thank Wilbert Hundl, Jr., and Jayson Lusk for considerable assistance with the survey form. Helpful comments from Rodney Holcomb, Jody Campiche, Nathan Kauffman, and Jason Brown are gratefully acknowledged. This research received funding from the Oklahoma Agricultural Experiment Station and the National Institute for Agriculture Hatch project OKL0293.

*Corresponding author's e-mail: wade.brorsen@okstate.edu 
often blamed for atmospheric environmental problems, including the discharge of methane, a potent greenhouse gas, into the atmosphere (Lashof and Ahuja, 1990; Zaks et al., 2011). Although livestock is not a net source of carbon dioxide, enteric fermentation and manure management account for almost 35\% of anthropogenic methane emissions in the United States (U.S. Environmental Protection Agency [USEPA], 2014a).

The agricultural sector accounts for approximately $19 \%$ of the energy use in the United States and is driven almost entirely by nonrenewable energy sources (Canning et al., 2010; Pimentel and Pimentel, 1996; Pimentel et al., 1973, 2008). Another nonrenewable resource that is important for production agriculture is phosphorus. Unfortunately, phosphorus is mostly obtained from mined rock phosphate, and these reserves are declining (Cordell, Drangert, and White, 2009; Shu et al., 2006). Although research has shown that world phosphorus reserves are finite, approximately $140,000 \mathrm{t}$ of this valuable nutrient are lost each year because of discharges from water reclamation facilities and runoff from agricultural lands (Aulenbach et al., 2007).

Anaerobic digestion could be a solution to the environmental and resource concerns created by confined animal agriculture. Anaerobic digestion systems alleviate greenhouse gas emissions by capturing and combusting methane. These systems can also precipitate and divert mineral phosphorus (as struvite, or magnesium ammonium phosphate, $\mathrm{NH}_{4} \mathrm{MgPO}_{4} \cdot 6 \mathrm{H}_{2} \mathrm{O}$ ) in a more concentrated form (Burns, Moody, and Shepherd, 2006; Çelen et al., 2007; Shu et al., 2006; Uysal, Yilmazel, and Demirer, 2010; Yilmazel and Demirer, 2011). By concentrating phosphorus, the nutrient can economically be shipped farther. According to Yilmazel and Demirer (2011) and others, struvite releases nutrients slowly and has low solubility in water. Phosphorus inputs with low water solubility are less likely to impair water quality (Zhang and Raun, 2006).

Despite the environmental and resource benefits associated with anaerobic digesters, the economics, and more specifically the capital costs, of these systems are often blamed for their limited adoption. USEPA (2012, 2014b) found only 239 of the almost $20,000(\sim 1 \%)$ confined animal feeding operations (AFOs) in the United States had anaerobic digestion systems, and the swine industry had only 29 of the 239 digesters. Most literature on the economic feasibility of anaerobic digestion systems in the United States has focused on the dairy industry (Bishop and Shumway, 2009; Kruger et al., 2008; Lazarus and Rudstrom, 2007; Stokes, Rajagopalan, and Stefanou, 2008; Wang et al., 2011). Some studies have begun to look more closely at the economic potential of anaerobic digesters with swine operations in the United States (Meinen, Kephart, and Graves, 2014), but most current literature is focused outside of the United States (Gan and Smith, 2011; Wilkinson, 2011).

When considering policies to encourage adoption, such as subsidies or mandates, it is important to understand the economics of these systems on swine operations in the United States and to determine the type of digestion that is the 
most economically feasible. Although "anaerobic digesters" is used as a general term, these systems can be split into two categories: biodigesters and covered lagoons. Biodigesters produce methane at a higher and more constant rate, whereas covered lagoons require lower maintenance, materials, and construction costs. Note that anaerobic bacteria will not produce biogas when temperatures are too low, so covered lagoons work best in warm climates. The primary objective is to determine the economic feasibility of biodigesters and covered lagoons on swine operations. The secondary objective is to determine the physical parameters, coproducts, and/or government policies needed to achieve economic feasibility with each type of system. The economic feasibility is estimated by calculating net present values (NPVs). The effects of different economic, coproduct, and policy scenarios on economic feasibility of the biodigesters and covered lagoons were determined with sensitivity analysis.

\section{Theory}

A discrete-choice maximization problem for a risk neutral producer that wants to determine the economic feasibility of extracting methane and other coproducts from manure produced at a swine AFO is as follows:

$$
\begin{aligned}
& \max _{n, d} N P V=\sum_{i=1}^{n}\left(\sum_{t=0}^{T}\left[\frac{p_{i t} E\left(y_{i t d}\right)-w_{i t d} x_{i t d}}{(1+r)^{t}}\right]-C_{i d}\right) \\
& \text { s.t. } N P V>0,
\end{aligned}
$$

where $n$ is a choice variable for the outputs that the producer wishes to produce; $i=1$ is recovered methane and $i=2, \ldots, n$ are any additional value-added coproducts; $d$ is the method used for handling swine manure, where $d=1,2$ (1 $=$ biodigester, 2 = covered lagoon); $r$ is the discount rate; $E\left(y_{i t d}\right)$ is the expected amount of the coproduct that is extracted in units/year; $p_{i t}$ is the price of each output in \$/unit; $w_{i t d}$ is the variable cost of inputs required to produce each coproduct in \$/unit; $x_{i t d}$ is the input, or physical parameter, required for the $i$ th coproduct in units/year; and $C_{i d}$ is the fixed cost of producing each coproduct.

\section{Data}

A questionnaire was distributed to all swine producers known to have anaerobic digesters with the help of the U.S. Department of Agriculture (USDA), National Agricultural Statistics Service. After obtaining informed consent for experimentation with human subjects, owners/operators of swine operations that currently use anaerobic digestion technology on their farms were asked to share cost, revenue, and production data from their anaerobic digester. Qualtrics Survey Software was used to create and administer the survey online, and a paper 
version of the survey was also sent in an attempt to generate additional responses. Responses were obtained between December 2013 and May 2014.

Of the 29 swine operations that operate anaerobic digesters in the United States, as identified by the USEPA AgSTAR Program, 8 responded to the survey (USEPA, 2014a). The eight completed surveys generated a response rate of almost $30 \%$. Two respondents operated covered lagoons, while the other six operated complete mix $(n=1)$ or plug flow $(n=5)$ biodigesters. Although all anaerobic digesters perform the same, basic functions, the most common ones are split into three categories: passive systems, low-rate systems, and high-rate systems. In passive systems, methane recovery is added to existing manure management infrastructure, and manure is the primary source of methane-forming microorganisms. In low-rate and high-rate systems, methaneforming microorganisms are added to or retained in the digester to increase methane production efficiency (Hamilton, 2013). To protect the confidentiality of the survey respondents, the two covered lagoons were grouped together, representing the "passive, low-cost" digesters, and the complete mix and plug flow biodigesters were grouped together, representing the "low-rate, high-cost" digesters.

The mean number of years that the biodigesters or covered lagoons were operational was approximately 8 years. Some of the swine farms reported that they also raise dairy cattle and that manure was not the only material entering the digestion system. The complete mix and plug flow biodigesters had an average of $25 \%$ food production or processing waste in the digester input stream. Astill and Shumway (2016) find that tipping fees from food waste can be a positive source of income that is not considered here. Both covered lagoons only processed swine manure. The average loading rate for the biodigesters was higher than the average loading rate for the covered lagoons, which is partially attributable to swine manure slurry having higher water content than dairy manure.

\section{Procedure}

NPV, as specified in equation (1), was used to compare the economic performance of biodigesters and covered lagoons. Because all anaerobic digesters produce methane, NPV was calculated for the average biodigester and covered lagoon on the basis of only methane production, and then additional outputs, such as electricity generation, struvite, and soil amendments were incorporated into the NPV calculation. Some of the agricultural operations included in this study reported trading carbon credits and receiving renewable energy tax credits and/or state or federal government grants. Therefore, any benefits from government policies and/or carbon trading were also added to the analysis. Prices for all possible coproducts are listed in Table 1, and all possible outputs and their corresponding revenues/cost savings, variable costs, and fixed costs are listed in Table 2. 
Table 1. Parameters used to calculate revenues and cost savings

\begin{tabular}{|c|c|c|c|}
\hline \multirow[b]{2}{*}{ Revenue or Cost-Saving Source } & \multirow[b]{2}{*}{ Units } & \multicolumn{2}{|c|}{ Mean Value } \\
\hline & & Biodigester & Covered Lagoon \\
\hline Installed capacity of electricity generator ${ }^{\mathrm{a}}$ & $\mathrm{kW}$ & 300 & 50 \\
\hline Electricity used on farm ${ }^{\mathrm{a}}$ & $\%$ & 33 & 100 \\
\hline Number of animals contributing manure ${ }^{a}$ & hogs & 5,250 & 5,000 \\
\hline Number of animals contributing manure ${ }^{\mathrm{a}}$ & cows & 620 & 0 \\
\hline Digester volume & $\mathrm{m}^{3}$ & 9,500 & 6,800 \\
\hline Manure produced by stock $\mathrm{b}^{\mathrm{b}}$ & L/hog/year & 1,500 & 1,900 \\
\hline Manure produced by stock $\mathrm{b}^{\mathrm{b}}$ & t/cow/year & 12 & 0 \\
\hline Nitrogen produced ${ }^{\mathrm{b}}$ & t/year & 31 & 7 \\
\hline Phosphorus produced ${ }^{\mathrm{b}}$ & t/year & 34 & 8 \\
\hline Average distance traveled to spread manure ${ }^{\mathrm{a}}$ & $\mathrm{km}$ & 2 & 0.8 \\
\hline Area of cropland that accepts manure $\mathrm{a}^{\mathrm{a}}$ & ha/year & 540 & 200 \\
\hline Wholesale electricity ${ }^{\mathrm{a}}$ & $\$ / k W h$ & \multicolumn{2}{|r|}{0.043} \\
\hline Retail electricity ${ }^{\mathrm{a}}$ & $\$ / \mathrm{kWh}$ & \multicolumn{2}{|r|}{0.075} \\
\hline P fertilizer ${ }^{\mathrm{d}}$ & $\$ / \mathrm{t}$ & \multicolumn{2}{|r|}{773} \\
\hline $\mathrm{N}$ fertilizer ${ }^{\mathrm{d}}$ & $\$ / \mathrm{t}$ & \multicolumn{2}{|r|}{452} \\
\hline Base manure handling charge: hauled ${ }^{e}$ & $\$ / \mathrm{L}$ & \multicolumn{2}{|r|}{0.033} \\
\hline Base manure handling charge: pumped ${ }^{\mathrm{e}}$ & $\$ / \mathrm{L}$ & \multicolumn{2}{|r|}{0.027} \\
\hline Unit $\mathrm{km}$ manure hauling charge $\mathrm{e}^{\mathrm{e}}$ & $\$ / \mathrm{L} / \mathrm{km}$ & \multicolumn{2}{|r|}{0.0002} \\
\hline Unit $\mathrm{km}$ manure pumping charge $\mathrm{e}^{\mathrm{e}}$ & $\$ / \mathrm{L}$ & \multicolumn{2}{|c|}{0.00388} \\
\hline Bulk soil amendment $\mathrm{f}^{\mathrm{f}}$ & $\$ / m^{3}$ & \multicolumn{2}{|r|}{19} \\
\hline Carbon trading on $\mathrm{CCX}^{\mathrm{g}}$ & $\$ / \mathrm{t}$ & \multicolumn{2}{|r|}{0.11} \\
\hline Carbon trading on ECX ${ }^{\mathrm{h}}$ & $\$ / t$ & \multicolumn{2}{|r|}{5.12} \\
\hline Social cost of carbon ${ }^{\mathrm{i}}$ & $\$ / \mathrm{t}$ & \multicolumn{2}{|r|}{12} \\
\hline Social Cost of carbon ${ }^{\mathrm{j}}$ & $\$ / \mathrm{t}$ & \multicolumn{2}{|r|}{38} \\
\hline
\end{tabular}

${ }^{a}$ Mean prices, as reported by survey respondents.

${ }^{b}$ U.S. Department of Agriculture (USDA), Natural Resources Conservation Service (2008).

${ }^{c}$ Calculated following methods by MidWest Plan Service (1985).

${ }^{\mathrm{d}}$ USDA, Economic Research Service (2014).

eFleming, Babcock, and Wang (1998) and Ribaudo et al. (2003).

${ }^{f}$ Price estimated from various sources.

${ }^{g}$ Chicago Climate Exchange (2013).

${ }^{\text {h}}$ European Climate Exchange (2014).

${ }^{i}$ For regulatory analysis: under Executive Order 12866, $r=5 \%$ (2013).

${ }^{\mathrm{j}}$ For regulatory analysis: under Executive Order 12866, $r=3 \%$ (2013).

\subsection{Economic Analysis: Revenues from Methane, Electricity, Struvite, and Other Coproducts}

According to the survey results, the methane generated by the biodigesters and covered lagoons was flared, used for furnace fuel, injected into an internal combustion engine for electricity generation, and/or compressed and used for vehicle fuel (compressed natural gas). The resulting annual revenue and/or cost savings from these practices, with the exception of electricity generation, is included in Figure 1 under the "Methane" heading. All biodigesters in this study produce methane that is injected into an electric generator, and one of the 
Table 2. Revenue/Cost Savings and Variable and Fixed Cost of Products

\begin{tabular}{|c|c|c|c|c|c|c|}
\hline \multirow[b]{2}{*}{ Product } & \multicolumn{3}{|c|}{ Biodigester } & \multicolumn{3}{|c|}{ Covered Lagoon } \\
\hline & $\begin{array}{l}\text { Revenue/ } \\
\text { Cost Savings }\end{array}$ & $\begin{array}{l}\text { Variable } \\
\text { Cost }\end{array}$ & Capital Investment & $\begin{array}{l}\text { Revenue/Cost } \\
\text { Savings }\end{array}$ & $\begin{array}{l}\text { Variable } \\
\text { Cost }\end{array}$ & Capital Investment \\
\hline Methane & $\$ 10,500^{\mathrm{a}}$ & $\$ 46,679^{\mathrm{b}}$ & $\$ 2,024,142^{\mathrm{c}}$ & $\$ 13,750$ & $\$ 52,863$ & $\$ 995,188$ \\
\hline Coproducts ${ }^{\mathrm{d}}$ & $\$ 39,167^{\mathrm{e}}$ & - & - & $\$ 50,000$ & - & - \\
\hline Electricity & $\$ 179,573^{\mathrm{f}}$ & $\$ 13,321^{\mathrm{g}}$ & $\$ 105,858^{\mathrm{h}}$ & $\$ 78,840$ & $\$ 2,137$ & $\$ 14,812$ \\
\hline Struvite & $\$ 27,805^{\mathrm{h}}$ & $\$ 13,921^{\mathrm{i}}$ & $\$ 429,518^{\mathrm{j}}$ & $\$ 17,397$ & $\$ 2,737$ & $\$ 334,621$ \\
\hline Grants $^{\mathrm{k}}$ & $\$ 1,228,326$ & - & - & $\$ 211,326$ & - & - \\
\hline $\begin{array}{l}\text { Carbon credits: } \\
\text { ECX }^{1}\end{array}$ & $\$ 44,746$ & - & - & $\$ 21,356$ & - & - \\
\hline $\begin{array}{l}\text { Carbon credits: } \\
\text { SCC } 12^{\mathrm{m}}\end{array}$ & $\$ 104,873$ & - & - & $\$ 50,052$ & - & - \\
\hline $\begin{array}{l}\text { Carbon credits: } \\
\text { SCC } 38^{\mathrm{n}}\end{array}$ & $\$ 340,836$ & - & - & $\$ 162,670$ & - & - \\
\hline
\end{tabular}

${ }^{a}$ Mean respondent annual benefit from methane used for furnace fuel and/or compressed and used for vehicle fuel (compressed natural gas).

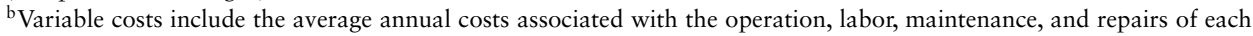
system and were obtained from survey respondents.

${ }^{\mathrm{c}}$ Respondents were asked to provide a capital investment cost that included the cost of all components in the system.

${ }^{\mathrm{d}}$ The cost to produce coproducts was included in the base costs of the methane biodigester or covered lagoon. Coproducts include compost soil amendments and animal bedding.

${ }^{\mathrm{e}}$ Annual benefit from coproducts given by survey respondents.

${ }_{\mathrm{f}}^{\mathrm{A}}$ Annual benefit from electricity is given by: $(67 \%$ electricity sold off-farm $\times \$ 0.043 / \mathrm{kWh}$ for wholesale electricity + $(100-67) \%$ electricity used on-farm $\times \$ 0.075 \mathrm{kWh}$ for retail electricity) $\times 85 \%$ generator operating time $\times 300 \mathrm{~kW}$ generator capacity $\times 24$ hours/day $\times 365$ days/year. All parameters except generator operating time are sample means. It was assumed that the generators operate and produce electricity at $85 \%$ of the reported installed capacity of the system in order to account for times when the generator is not operating or is operating at less than full capacity.

${ }^{g}$ Obtained from RSMeans (2013) for the mean respondent electric generator capacity from survey, $300 \mathrm{~kW}$.

${ }^{\mathrm{h}}$ Annual benefit from struvite is based on the value of the extracted phosphorus fertilizer and cost savings associated with transporting the precipitated struvite for phosphorus fertilizer instead of bulk manure. Cowley (2015, pp. 11-15, 55-71) provides a detailed description of struvite valuation and transportation cost savings.

${ }^{\mathrm{i}}$ Estimated variable costs were derived from literature on existing struvite extraction applications for municipal waste water reclamation, and the amounts and costs of chemicals required to maintain $\mathrm{pH}$ and magnesium at levels necessary for optimal extraction of phosphorus as struvite were also considered (Shu et al., 2006). The variable cost of the chemicals required for extracting struvite was $\$ 1.65 /$ day, or about $\$ 600 /$ year. The variable costs of operating and maintaining a struvite precipitator were the same as the variable costs of operating and maintaining an electric generator set.

jObtained from RSMeans (2013) for reactor container (with a tapered bottom), stirring system, stand mechanism, filter, pipes, and fittings (Etter, 2009).

${ }^{\mathrm{k}}$ Mean respondent benefit from government grants was $49 \%$ for biodigesters and $13 \%$ for covered lagoons.

${ }^{1}$ Annual benefit from carbon credits on the European Climate Exchange (ECX) were based on a price of \$5.12/t (ECX, 2014), an estimated volume of methane gas for each biodigester and covered lagoon using the universal gas law, methane conversion factors from the Intergovernmental Panel on Climate Change (IPCC) Guidelines for National Greenhouse Gas Inventories (Dong et al., 2006), and the carbon dioxide equivalent for methane from the IPCC (1996), which determined that the global warming potential of methane is 25 times that of carbon dioxide. Cowley $(2015$, pp. 46-49) provides a detailed description of the methodology for estimating methane yield and the amount of carbon offset by the anaerobic digestion systems.

${ }^{m}$ Annual benefit from carbon credits on the social cost of carbon (SCC) were based on a price of $\$ 12 / t$, which is estimated at a discount rate of $5 \%$.

${ }^{\mathrm{n}}$ Annual benefit from carbon credits on the SCC were based on a price of $\$ 38 / \mathrm{t}$, which is estimated at a $3 \%$ discount rate. Note that other technology such as conservation tillage (Wade, Kurkalova, and Secchi, 2016) might outcompete digesters, and so such a price might not be feasible.

Note: The survey responses are based on herds that averaged about 5,000 head of swine that weighed 55 pounds or more. Although only $5 \%$ of U.S. hog operations had 5,000 or more head in 2012, these large operations accounted for 93\% of the annual pig crop in 2014 (U.S. Department of Agriculture, National Agricultural Statistics Service, 2015). A discount rate of $6 \%$ and a project life of 25 years were used, which are consistent with previous literature (Bishop and Shumway, 2009; Tchobanoglous et al., 2014; U.S. Army Corps of Engineers, 2011). 


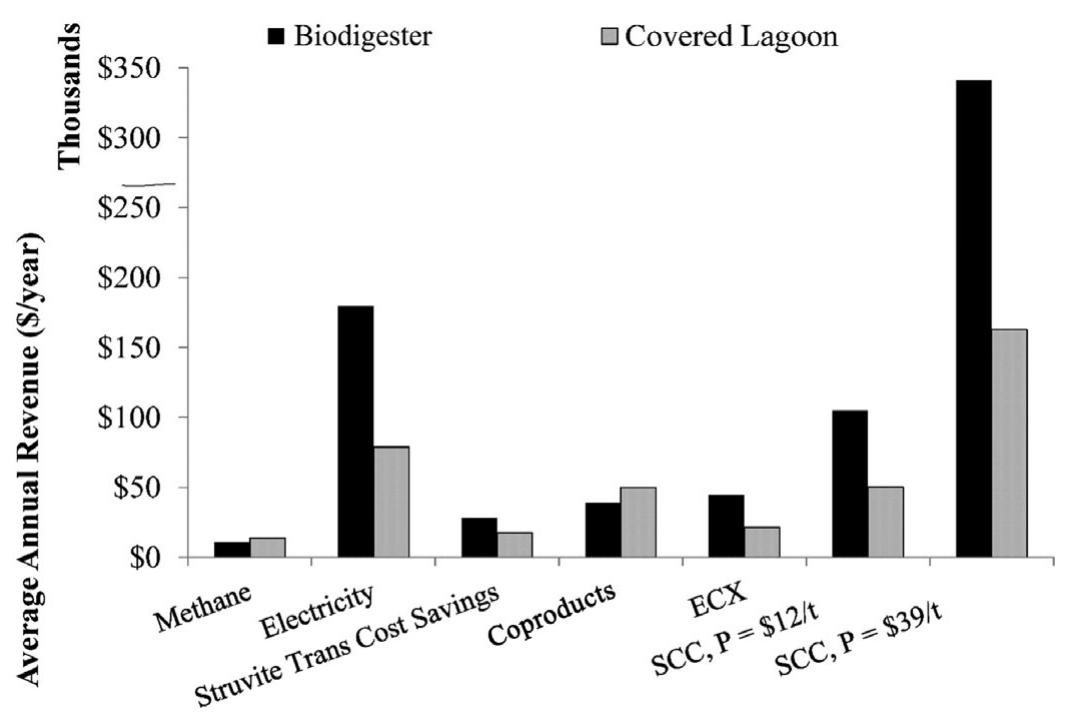

\section{Sources of Revenue or Cost Savings}

Figure 1. Mean Annual Revenues from Alternative Sources (note: ECX, European Climate Exchange; SCC, social cost of carbon)

covered lagoons reported electricity generation. Farmers sell the electricity off the farm at a wholesale price and/or use it to offset their own (retail) costs of electricity. The average price at which farmers sell this electricity is included in Table 1 as the wholesale price of electricity. The average price farmers pay for electricity is included in Table 1 as the retail price of electricity. The average annual revenue and cost savings for the biodigesters and covered lagoons are included in Figure 1.

Anaerobic digestion systems could potentially precipitate mineral phosphorus (as struvite) if a struvite precipitator is added to the system (Burns, Moody, and Shepherd, 2006; Çelen et al., 2007; Shu et al., 2006; Uysal, Yilmazel, and Demirer, 2010; Yilmazel and Demirer, 2011). Precipitation of struvite could reduce manure and nutrient transportation costs. Using similar methods as Fleming, Babcock, and Wang (1998) to compute costs of transporting, spreading, and incorporating manure, an equation for transportation cost savings resulting from the precipitation of struvite was specified as

$$
\pi_{3 d}=\varphi_{k}\left(\sum_{k=1}^{K} P_{k} N_{k}-\sum_{k=1}^{K} \sum_{j=1}^{J} Q_{j} H_{j}\left[r_{B}+Z r_{A}\left(D+2 \sqrt{A_{k j} / 640}\right)\right]\right),
$$

where $\pi_{3 d}$ is the value of transportation cost savings in $\$ /$ year; $P_{k}$ is the price of nutrient $k$ in $\$ / t$, where $k=1$ is nitrogen and $k=2$ is phosphorus; $N_{k}$ is the quantity of nutrient $k$ produced per year in $t ; Q_{j}$ is the quantity of manure (or struvite) 
produced by breeding or feeding stock $j$ in L/animal units (AU)/year, where $j$ equals 1 for nursery pigs, 2 for grow-to-finish pigs, 3 for breeding sows, 4 for dairy cows, and 5 for dairy heifers; $H_{j}$ is the number of AU contributing manure; $r_{A}$ is the unit kilometer charge in $\$ / \mathrm{L} / \mathrm{km} ; r_{B}$ is the base charge in $\$ / \mathrm{L} ; Z$ is an indicator variable and equals 2 for slurry systems (round trip for hauling vehicle) or 1 for liquid waste (pumped, no return trip required); $D$ is the average distance traveled to spread manure over spreadable land that accepts manure in kilometers; $A_{k j}$ is the spreadable area of cropland that accepts manure in ha/year; and $\varphi_{k}$ represents the portion ( $\%$ ) of nutrient $k$ precipitated out or remaining in the manure.

Mean values for all parameter values used in the calculations of coproduct revenues and cost savings are included in Table 1.

Struvite precipitation can extract $90 \%-95 \%$ of the available phosphorus and about $15 \%$ of the available nitrogen in livestock manure (Burns, Moody, and Shepherd, 2006; Çelen et al., 2007; Shu et al., 2006; Sommer et al., 2013; Uysal, Yilmazel, and Demirer, 2010; Yilmazel and Demirer, 2011). A recoverability factor of 0.9 was used to give a conservative estimate of the phosphorus recovered as struvite. Because fertilizer is available in a more concentrated form after struvite precipitation, a farmer could transport the material farther. Because most of the phosphorus is extracted during struvite precipitation, a farmer may not have to haul the processed manure as far. We assume that the remaining manure, which will contain some nutrients (approximately $85 \% \mathrm{~N}$ and $10 \% \mathrm{P}$, by weight of manure), is applied to cropland.

Precipitating mineral phosphorus as struvite and utilizing the remaining manure nutrients avoids costs of purchasing fertilizer and/or allows selling the manure or struvite as fertilizer to others. Although struvite is primarily known as phosphorus fertilizer, it also contains nitrogen. The fertilizer equivalent of struvite is approximately $6-9-0$, as $\mathrm{N}-\mathrm{P}_{2} \mathrm{O}_{5}-\mathrm{K}_{2} \mathrm{O}$ (Bridger, Salutsky, and Starostka, 1962). The price of superphosphate $(44 \%-46 \%$ phosphate) as of March 2013 was $\$ 773 / \mathrm{t}$, and the price of nitrogen solutions (30\% nitrogen) was \$452/t (USDA, Economic Research Service [ERS], 2014). USDA-ERS (2014) fertilizer prices were used for manure and struvite nutrients. Because the amount and value of the nutrients from manure and struvite will be the same, the primary benefit to the swine producer is transportation cost savings.

Manure transportation calculations assume that AFOs require land to dispose of annual manure (and nutrient) production. The land area $\left(A_{k j}\right)$ required for manure disposal was calculated based on the amount of manure excreted by animal units on the farm, the nutrient content of the manure, and the nutrient utilization of the receiving crop. The equation for total cropland required for manure (or struvite) application is

$$
A_{k j}=\sum_{j=1}^{J} \frac{Q_{j} H_{j} \rho_{k j}}{\mu_{k}}
$$


where $\rho_{k j}$ is production of nutrient $k$ by animal $j$ in $\mathrm{kg} / \mathrm{L}$ manure, $\mu_{k}$ is the crop nutrient utilization in $\mathrm{kg} / \mathrm{ha}$ of nutrient $i$, and all other variables are the same as given previously. USDA, Natural Resources Conservation Service (2008) gives volume of manure and mass of nutrients produced per animal unit per day by type of animal, and this information was used to calculate $\rho_{k j}$.

The eight swine AFOs are located where corn is a primary crop, so corn was the crop chosen for manure transportation calculations. The average yield in these areas was approximately 150 bushels per acre. For $10 \mathrm{t} / \mathrm{ha}$, corn uses $207 \mathrm{~kg} / \mathrm{ha}$ nitrogen and $90 \mathrm{~kg} / \mathrm{ha} \mathrm{P}_{2} \mathrm{O}_{5}$ (MWPS, 1985). The land area required for each nutrient was calculated, and the larger of the two areas was selected for transportation cost calculations in equation (2). Manure management laws in each of the included states assert that manure nutrient application cannot exceed crop $\mathrm{N}$ requirements. Individual state laws are not cited here in order to protect survey respondent confidentiality. Application of phosphorus may be greater than crop requirements when soil tests indicate low phosphorus levels but must not exceed crop requirements when soil tests indicate phosphorus levels are adequate. However, laws governing land application of manure phosphorus are more stringent when the land is within a certain distance of surface water (typically 30 to $300 \mathrm{~m}$, depending on the state and the type of water body).

Based on Beal, Burns, and Stalder (1999), a swine farm could produce $113 \mathrm{~kg} /$ year/AU struvite. The volume of struvite (in L/year) was calculated using the density of struvite $(1.8 \mathrm{~kg} / \mathrm{L})$ and unit conversion factors. The volume of struvite was inserted into equations (2) and (3) in place of $Q_{j}$ to determine the costs of transporting, spreading, and incorporating struvite fertilizer.

The biodigesters and covered lagoons also reported revenue and/or cost savings from coproducts, such as animal bedding and compost soil amendments. Survey respondents were asked to report revenue and cost-savings information, and these values are included in Table 2 and Figure 1.

\subsection{Economic Analysis: Government Intervention}

Only one biodigester operator and one covered lagoon operator reported no help in the form of government grants. Government grants paid for a percentage of the capital costs of constructing the biodigesters or covered lagoons. Cowley and Brorsen (2018) found that government grants were a key reason that producers adopted anaerobic digesters. The average of those receiving government grants is included in Figure 2 and was included in the NPV analysis.

Some respondents reported benefiting from carbon trading, whether through the Chicago Climate Exchange (CCX) or another outlet. Farms and businesses in the United States cannot trade on the European Climate Exchange (ECX) at this time, but the ECX does present a price of carbon that can be used for economic analysis. The price at which carbon was traded on the ECX at the time this research was conducted $(\$ 5.12 / \mathrm{t}$; ECX, 2014) is similar to the price that carbon could be traded in the United States because of recent actions by state 


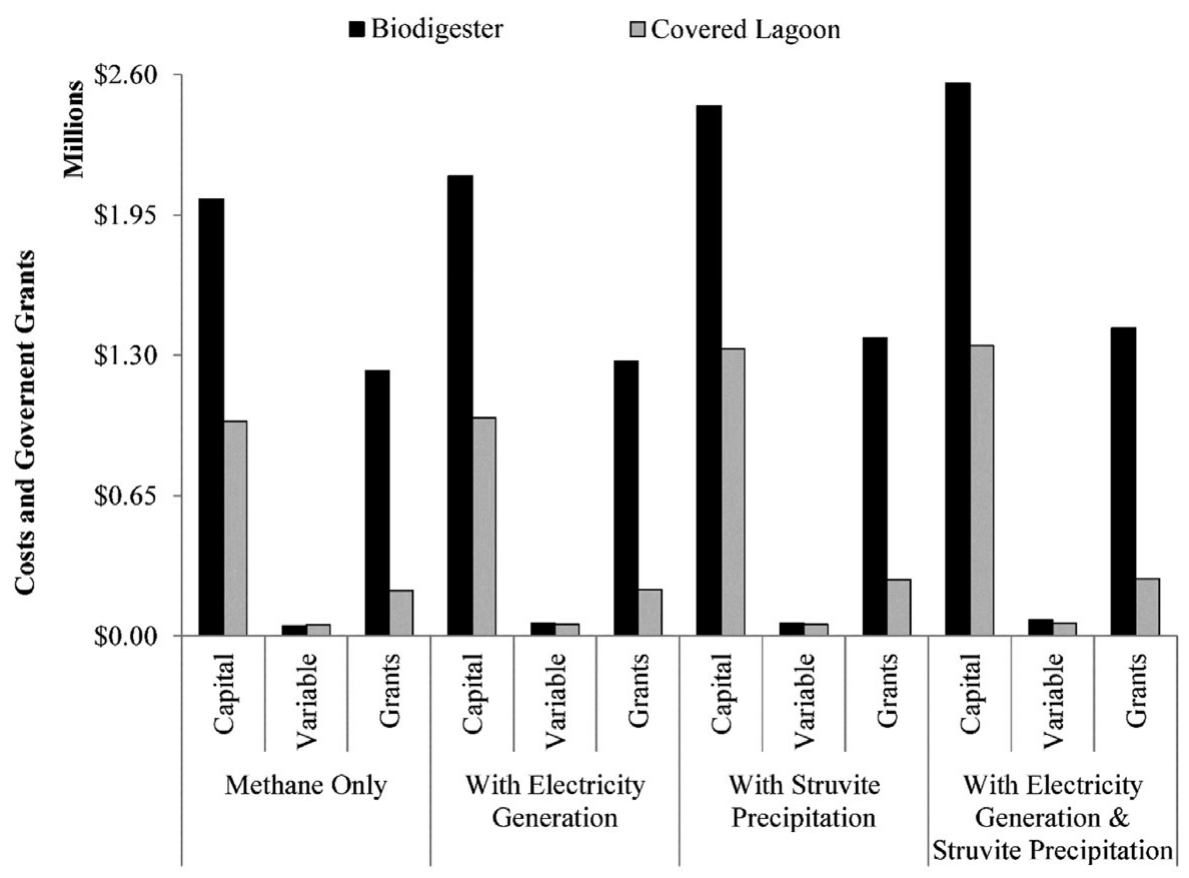

Figure 2. Fixed and Variable Costs under Alternative Scenarios

governments. For example, in 2006 the state of California passed the Global Warming Solutions Act (AB 32), which instituted a cap-and-trade program to reduce greenhouse gas emissions. The California Air Resources Board approved the Climate Action Reserve and the American Carbon Registry to serve as offset project registries for the compliance offset program under the cap-and-trade program. Supply and demand models of the carbon offset market forecast prices at about $\$ 5$ to $\$ 15 / \mathrm{t}$ (Borenstein et al., 2014).

In addition, under Executive Order 12866, the social cost of carbon (SCC) was determined to allow agencies to include the social benefits of reducing carbon dioxide $\left(\mathrm{CO}_{2}\right)$ emissions into cost-benefit analysis of regulatory actions (Interagency Working Group on Social Cost of Greenhouse Gases, 2013, pp. 12). The actual price obtained for carbon credits on the CCX in $2010(\$ 0.11 / \mathrm{t})$ was much less than the government-specified SCC ( $\$ 12$ to $\$ 105 / \mathrm{t}$ ) (CCX, 2013; Interagency Working Group on Social Cost of Greenhouse Gases, 2013). The market price being lower than SCC could be attributable to the carbon cap being below the socially optimal level. If the cap on carbon emissions tightens, the market price of carbon could increase. However, the SCC could be overstated if the ability to adapt (McCarl, Thayer, and Jones, 2016) is underestimated. The Interagency Working Group on Social Cost of Greenhouse Gases (2013) used three integrated assessment models that included changes in net agricultural 
productivity, human health, property damages from increased flood risk, and the value of ecosystem services because of climate change, among other parameters, to estimate an average SCC at discount rates of $2.5 \%, 3 \%$, and $5 \%$. According to the Interagency Working Group on Social Cost of Greenhouse Gases (2013, p. 12), a discount rate of $3 \%$ is typically used because "the $3 \%$ discount rate is the central value, and so the central value that emerges is the average SCC across models at the $3 \%$ discount rate."

The SCC has widely acknowledged limitations, is a shadow price that measures the marginal benefit of emissions reductions, and is deduced from a mode of climate dynamics and economic impacts (Ackerman and Stanton, 2012). To determine the potential effects of the swine methane emissions being priced at the SCC, the amount of methane captured and combusted on each farm, resulting in offset carbon emissions, was calculated following the methods described by Cowley (2015, pp. 46-49). Although the SCC estimates the monetized damages to society associated with an incremental increase in carbon emissions, it is also the value of damages avoided by emissions reduction. In this study, the SCC prices, like the price on the ECX, are assumed to be possible prices that a farmer could receive for carbon offsets.

Imposing the SCC on the entire economy could increase electricity rates. Several studies have described this phenomenon, which is known as price "pass-through" (Kim, Chattopadhyay, and Park, 2010). Depending on how electricity prices are determined (regulated or market) and how carbon credits are distributed (e.g., auction vs. free distribution), policies that regulate carbon emissions could result in the prices of electricity increasing by $1 \%$ to $15 \%$ (Bird, Holt, and Carroll, 2008). However, the current study does not account for the potential rise in electricity prices resulting from policies like the Global Warming Solutions Act and the SCC.

This study also does not incorporate energy prices or their variability into the analysis. Several studies have examined the effects of oil prices on bioenergy production, consumption, and feasibility on a macrolevel. Gan and Smith (2011) concluded that although energy prices could be potential drivers for bioenergy, they had an insignificant impact on bioenergy supply in Organization for Economic Cooperation and Development countries. Similarly, on the demand side, Omri, Daly, and Nguyen (2015, p. 2913) found limited evidence of oil price effects on renewable energy consumption and concluded that "renewable energy is just a complement and not a perfect substitute of crude oil" in the short run. Future studies may want to more deeply study the relationship between digesters and energy prices; however, this is outside the scope of the present research.

\subsection{Economic Analysis: Fixed and Variable Costs}

Respondents were asked to provide a capital investment cost that included the cost of all components in the system. After converting all capital cost values to 2014 dollars, the mean size, capital costs, and variable costs were calculated 
for the biodigesters and covered lagoons. As expected, the average cost for the biodigesters was larger than the average costs for the covered lagoons. Variable costs include the average annual costs associated with the operation, labor, maintenance, and repairs of each system (see Table 2).

NPV was first calculated for the average biodigester and covered lagoon on the basis of only methane production. Therefore, costs had to be adjusted. The total cost of the system was reduced for only methane production because the system would not include an electricity generator. The estimated fixed and variable costs of electric generators were obtained from RSMeans (2013). Installed capacities for each biodigester and covered lagoon were provided by the survey respondent. The cost estimates for the electricity generator set were subtracted from the cost values provided by the survey respondents, and the resulting cost estimates used for scenarios that excluded electricity generation are in Figure 2.

It was more difficult to determine the fixed and variable costs of recovering phosphorus via struvite precipitation because, although the technical literature for struvite extraction is becoming more prevalent, the economics of this technology have not been thoroughly researched (Çelen et al., 2007; Uysal, Yilmazel, and Demirer, 2010). In addition to the already established biodigester or covered lagoon system, the setup for struvite precipitation consists of a reactor container (with a tapered bottom), stirring system, stand mechanism, filter, pipes, and fittings (Etter, 2009). The technical literature was used to estimate the sizes and types of materials needed to construct the struvite precipitator, and RSMeans (2013) provided the cost estimates for materials and construction.

Sensitivity analyses were used to determine how the economic feasibility of the digester is affected by including each of the coproducts, government incentive programs, phosphorus extraction, and carbon trading (or carbon offset). Costs were assumed unchanged for all other coproduct marketing and government policy scenarios. The only sources of change were whether or not electricity was generated and phosphorus was precipitated as struvite (see Table 2). After calculating average costs and revenues, equation (1) was used to determine the NPV of the digester under the different scenarios. A discount rate of $6 \%$ and a project life of 25 years were used, which are consistent with previous literature (Bishop and Shumway, 2009; Tchobanoglous et al., 2014; U.S. Army Corps of Engineers, 2011).

\section{Results and Discussion}

Figure 1 summarizes revenue information for the biodigesters and covered lagoons. For all revenue sources except methane and coproducts, the biodigesters are more productive. Most of the methane produced by the biodigesters is used to generate electricity. Figure 2 depicts the fixed costs, variable costs, and government grants for the biodigesters and covered lagoons. Although government grants are technically a source of revenue, they are included with 


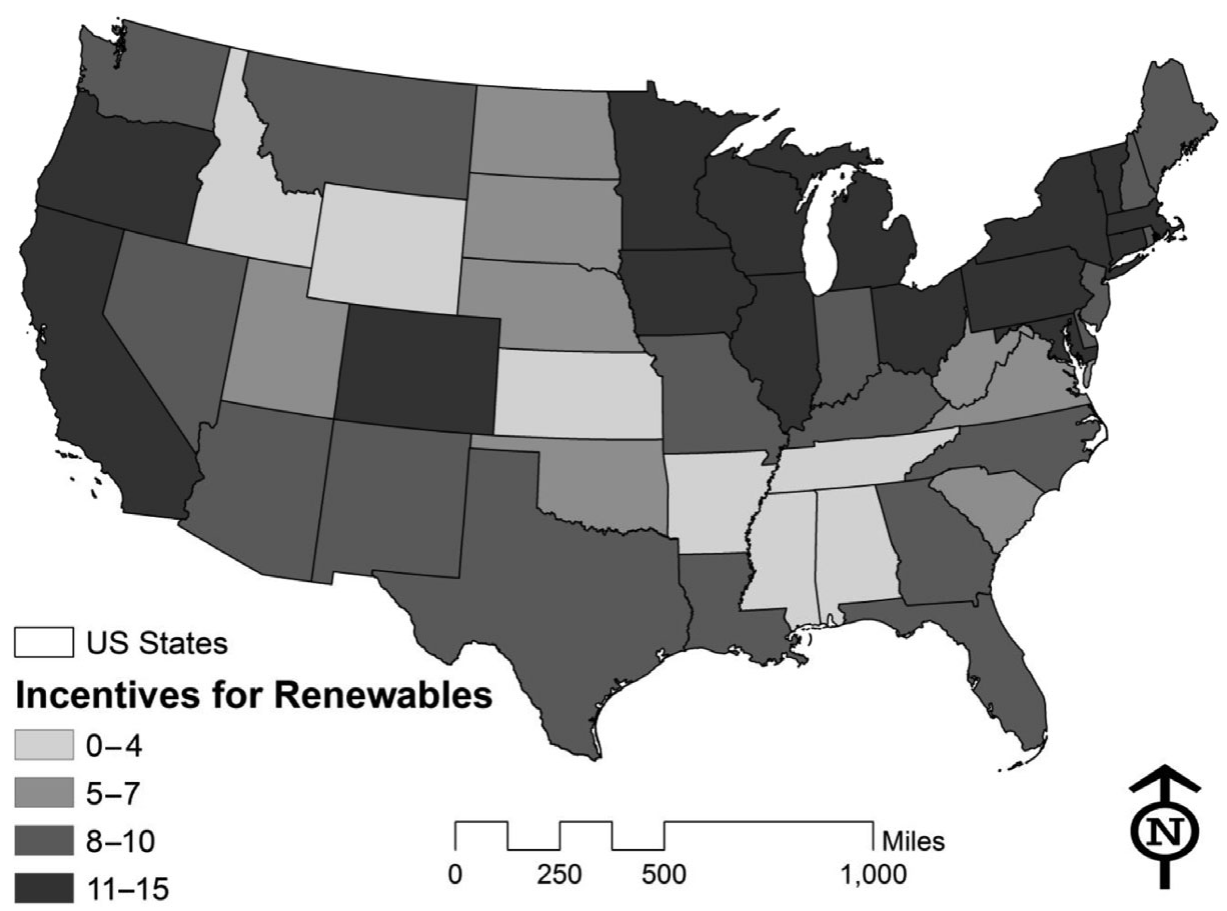

Figure 3. Number of Financial Incentives and Regulatory Policies That Promote Renewable Energy in Each U.S. State (U.S. Department of Energy, 2014)

the costs because they are allocated as a percentage of the fixed cost of each system. Although provided in Figure 2, government grants were not included in the NPV analysis for the systems with struvite precipitation because that was a hypothetical scenario. The fixed costs for biodigesters are about twice as large as the fixed costs for covered lagoons. Fixed costs are also significantly larger than the variable costs of each system. When government grants are applied to the biodigesters, the costs of the systems are reduced by half and draw closer to the fixed costs of the covered lagoon systems.

It is also clear from Figures 1 and 2 that the three largest potential revenue sources are electricity generation, carbon credits, and government grants. Therefore, it may be important for swine producers who are interested in anaerobic digestion to understand the likelihood or feasibility of benefiting from each of these markets and/or government policies. The U.S. Department of Energy (USDOE) maintains the Database of State Incentives for Renewables \& Efficiency (DSIRE) (USDOE, 2014), which lists 14 different financial incentives and regulatory policies that promote renewable energy at the state or local level. Figure 3 summarizes the concentration of these policies in each state. A state received a point for having a statewide policy and another point for policies 
Table 3. Net Present Values for Biodigesters and Covered Lagoons on Swine Farms at $r=6 \%$

\begin{tabular}{lll}
\hline \hline Revenue Source Scenario & Biodigester & Covered Lagoon \\
\hline Methane only & $(\$ 2,486,631)$ & $(\$ 1,495,183)$ \\
Methane + struvite & $(\$ 2,738,665)$ & $(\$ 1,642,400)$ \\
Methane + coproducts & $(\$ 1,985,945)$ & $(\$ 856,016)$ \\
Methane + electricity & $(\$ 1,083,043)$ & $(\$ 529,474)$ \\
Methane + SCC12 & $(\$ 1,146,002)$ & $(\$ 855,351)$ \\
Methane + coproducts + SCC12 & $(\$ 645,316)$ & $(\$ 216,183)$ \\
Methane + electricity + coproducts & $\$ 33,455$ & $\$ 109,694$ \\
Methane + electricity + SCC12 & $\$ 265,590$ & $\$ 110,359$ \\
Methane + electricity + coproducts + grants & $\$ 1,308,338$ & $\$ 325,019$ \\
Methane + electricity + coproducts + SCC12 & $\$ 1,374,084$ & $\$ 749,527$ \\
Methane + electricity + coproducts + grants + SCC12 & $\$ 2,648,967$ & $\$ 964,852$ \\
\hline \hline
\end{tabular}

Note: ECX, European Climate Exchange; SCC, social cost of carbon.

on the local level. Only policies dealing with renewable electricity production, greenhouse gas emission offsets, and grants were considered. Generally, revenues for renewable electricity are dependent on state policies, and as shown in Figure 3, some states offer more financial incentives and regulatory policies than others. As for carbon credits, California recently passed the Global Warming Solutions Act. Although the act was passed in California, it is expected that carbon trading would occur on a national level.

Because of the large capital investment required to purchase a biodigester or covered lagoon, NPVs for the production of only methane are negative (Table 3). Therefore, it is not likely that a swine farm would adopt a biodigester or covered lagoon for manure management if it could produce only methane. These results correspond with similar studies carried out in the dairy industry (Bishop and Shumway, 2009; Stokes, Rajagopalan, and Stefanou, 2008).

NPVs remained negative for all scenarios that did not include electricity generation. The addition of coproduct markets, such as bulk soil amendments and animal bedding were not enough to overcome the large capital costs of biodigester or covered lagoon installation. The addition of only electricity generation did not produce a positive NPV. Most economic feasibility analyses of anaerobic digestion systems on dairy farms have included the production of methane and electricity and have also found that anaerobic digesters are not economically feasible (Bishop and Shumway, 2009; Garrison et al., 2003). However, producing methane and electricity along with other coproducts on a swine operation does produce a positive NPV for biodigesters and covered lagoons.

Even without the assistance of government grants, the NPV for the covered lagoon that produces methane, electricity, and coproducts is positive and larger than the same NPV for biodigesters. The application of struvite precipitation with a biodigester or covered lagoon is not a common practice on AFOs. This technology is expensive and primarily used for municipal and experimental 
purposes. Costs of struvite precipitation were too large to make their addition to the biodigester or covered lagoon economically feasible without other revenue sources. After the struvite is precipitated out, the remaining manure must still be shipped for disposal and/or land application, so the transportation cost savings are small when compared with some of the other revenue sources. When added to the analysis, struvite precipitation decreased, rather than increased, the NPV. Other studies have indicated that the primary benefits generated from the precipitation of struvite included reduced reliance on chemicals and maintenance and cleaning cost savings because of decreased struvite incrustations on equipment (Maßß, Grundmann, and von Bock von Polach, 2014; Shu et al., 2006). Although outside the scope of this analysis, these considerations could be included in future studies of anaerobic digestion with struvite precipitation on swine operations.

The addition of government grants made less difference in the NPV of the covered lagoon system because the initial costs and the percent paid by the government were smaller than the corresponding values for the biodigesters. However, the addition of government grants resulted in a positive NPV for the complete mix and plug flow biodigesters, which was larger than the NPV for the covered lagoon. Carbon trading at an SCC of $\$ 12 / \mathrm{t}$ increased the NPVs for all scenarios, and this increase was enough to make the NPV for biodigesters positive without government assistance in the scenarios where methane and electricity were also produced. Similar results were obtained when adding carbon trading on the ECX or at an SCC of $\$ 38 / \mathrm{t}$. For biodigesters, an additional dollar per ton of carbon in carbon trading resulted in more than $\$ 110,000$ in NPV, and approximately $\$ 55,000$ was added to the NPV for covered lagoons for an additional $\$ 1 / t$ of carbon. In fact, the NPV was positive in scenarios that included an SCC of $\$ 38 / \mathrm{t}$ in addition to methane and coproducts with no electricity generation. The NPV for biodigesters was larger than the NPV for covered lagoons in all scenarios that included carbon trading.

\section{Conclusions}

In the absence of government grants for capital investment and carbon trading, the covered lagoon was able to achieve a larger NPV than the biodigester when the cost of capital was assumed to be $6 \%$. Precipitating mineral phosphorus as struvite as a part of a biodigester or covered lagoon is still somewhat hypothetical, and transportation cost savings are not enough to improve economic feasibility.

Being able to trade on the ECX and valuing carbon offsets with the government-specified SCC, along with methane, coproduct, and electricity markets, resulted in positive NPVs for biodigesters and covered lagoons. These scenarios are only theoretical, but it is important to understand how carbon trade policy and/or government mandates on the cost of carbon could affect 
the economic feasibility of renewable energy systems on swine farms. Unlike electricity generation and struvite precipitation, carbon trading requires no additional costs to the producer. With a biodigester or covered lagoon, methane is already captured, and most systems include a flare. Having the ability to trade or sell carbon credits could improve the economic feasibility of biodigesters and covered lagoons. Although more expensive, biodigesters obtained positive NPVs when only producing methane, electricity, and carbon for trading at the ECX and SCC prices. Biodigesters have more control over the parameters that affect methane production (e.g., temperature, retention time, microbial activity). Because of this, biodigesters extract and capture more methane at a more consistent rate and could benefit more from carbon trading than covered lagoons.

In summary, electricity generation and coproducts are required to make covered lagoons a potentially viable option for handling swine manure. When coproduct markets, electricity generation, and government grants are available, biodigesters and covered lagoons both resulted in positive NPVs. However, a positive NPV does not necessarily guarantee economic feasibility for all agricultural operations. Cost of capital and desired rate of return on investment vary among producers and could have a significant effect on whether a biodigester or covered lagoon project is pursued. Because carbon trading is limited in the United States, struvite precipitation is not a widespread technology, and government grants for renewable energy technologies vary among states, covered lagoons could have more potential than biodigesters on swine operations. Only about $1 \%$ of farms in the United States operate biodigesters or covered lagoons. Biodigesters and covered lagoons exist either because the producers received government grants or the producers are willing to accept relatively low returns on capital.

Although covered lagoons may produce methane, electricity, and other coproducts at a slower and more inconsistent rate than biodigesters, the benefits of the system could be enough to cover the lower costs of construction and maintenance. Overall, in order to make biodigesters or covered lagoons work, they will need lower costs, electricity and coproduct generation, and government subsidies. Otherwise, they will remain a marginal investment at best. Government grants are mostly applied to biodigesters. For swine manure, covered lagoons seem more promising than biodigesters, so one policy recommendation could be to reallocate government subsidies on swine AFOs to focus on covered lagoons.

\section{References}

Ackerman, F., and E.A. Stanton. "Climate Risks and Carbon Prices: Revising the Social Cost of Carbon.” Economics 6,10(2012):1-25.

Astill, G.M., and C.R. Shumway. "Profits from Pollutants: Economic Feasibility of Integrated Anaerobic Digester and Nutrient Management Systems." Journal of Environmental Management 184,2(2016):353-62. 
Aulenbach, B.T., H.T. Buxton, W.A. Battaglin, and R.H. Coupe. Streamflow and Nutrient Fluxes of the Mississippi-Atchafalaya River Basin and Subbasins for the Period of Record through 2005. U.S. Geological Survey Open-File Report 2007-1080, 2007. Internet site: http://toxics.usgs.gov/pubs/of-2007-1080/ (Accessed 10 October 2012).

Beal, L.J., R.T. Burns, and K.J. Stalder. "Effects of Anaerobic Digestion on Struvite Production for Nutrient Removal from Swine Waste Prior to Land Application." Paper presented at the ASAE Annual International Meeting, Toronto, Ontario, Canada, July 18-21, 1999.

Bird, L.A., E. Holt, and G.L. Carroll. "Implications of Carbon Cap-and-Trade for US Voluntary Renewable Energy Markets.” Energy Policy 36,6(2008):2063-73.

Bishop, C.P., and C.R. Shumway. "The Economics of Dairy Anaerobic Digestion with Coproduct Marketing.” Review of Agricultural Economics 31,3(2009):394-410.

Borenstein, S., J. Bushnell, F.A. Wolak, and M. Zaragoza-Watkins. "Report of the Market Simulation Group on Competitive Supply/Demand Balance in the California Allowance Market and the Potential for Market Manipulation.” Paper presented at the public meeting of the Emissions Market Advisory Committee (EMAC), Berkeley, California, 2014.

Bridger, G.L., M.L. Salutsky, and R.W. Starostka. "Metal Ammonium Phosphates as Fertilizers." Journal of Agricultural and Food Chemistry 10,3(1962):181-88.

Burns, R.T., L. Moody, and T. Shepherd. Concentration and Extraction of Phosphorus from Swine Manure Slurries (as Struvite). Ames: Iowa State University, Animal Industry Report, AS 652 ASL R2120, 2006.

Canning, P., A. Charles, S. Huang, K.R. Polenske, and A. Waters. Energy Use in the U.S. Food System. Washington, DC: U.S. Department of Agriculture, Economic Research Service, Economic Research Report No. 94, March 2010.

Carpenter, S.R., N.F. Caraco, D.L. Correll, R.W. Howarth, A.N. Sharpley, and V.H. Smith. "Nonpoint Pollution of Surface Waters with Phosphorus and Nitrogen." Ecological Applications 8,3(1998):559-68.

Çelen, I., J.R. Buchanan, R.T. Burns, R.B. Robinson, and D.R. Raman. "Using a Chemical Equilibrium Model to Predict Amendments Required to Precipitate Phosphorus as Struvite in Liquid Swine Manure." Water Research 41,8(2007): 1689-96.

Centner, T.J. "Regulating Concentrated Animal Feeding Operations to Enhance the Environment." Environmental Science \& Policy 6,5(2003):433-40.

Chicago Climate Exchange (CCX). "Henry Hub Natural Gas Futures, Dec 2012." Internet site: https://web.archive.org/web/20100919011017/http://chicagoclimatex.com/ market/data/summary.jsf (Accessed October 5, 2013).

Cordell, D., J-O. Drangert, and S. White. "The Story of Phosphorus: Global Food Security and Food for Thought.” Global Environmental Change 19,2(2009):292-305.

Cowley, C. “Anaerobic Digester Adoption on Animal Feeding Operations.” Ph.D. dissertation, Oklahoma State University, Stillwater, 2015.

Cowley, C., and B.W. Brorsen. "The Hurdles to Greater Adoption of Anaerobic Digesters." Agricultural and Resource Economics Review 47,1(2018):132-57.

Dong, H., J. Mangino, T.A. McAllister, J.L. Hatfield, D.E. Johnson, K.R. Lassey, M. Aparecida de Lima, and A. Romanovskaya. "Chapter 10: Emissions from Livestock and Manure Management.” 2006 IPCC Guidelines for National Greenhouse Gas Inventories. Vol. 4, Agriculture, Forestry and Other Land Use. S., L., K., T., and K., eds. Hayama, Japan: Institute for Global Environmental Strategies (IGES) on behalf of IPCC, 2006, pp. 10.110.87 . 
Etter, B. “Process Optimization of Low-Cost Struvite Recovery.” Master's thesis, Swiss Federal Institute of Technology in Lausanne (EPFL), 2009.

European Climate Exchange (ECX). Carbon Futures, Jun 2012, 2014. Internet site: https: //www.theice.com/products/197/EUA-Futures/specs (Accessed May 18, 2014).

Fleming, R.A., B.A. Babcock, and E. Wang. "Resource or Waste? The Economics of Swine Manure Storage and Management." Review of Agricultural Economics 20,1(1998):96113.

Gan, J., and C.T. Smith. "Drivers for Renewable Energy: A Comparison among OECD Countries." Biomass and Bioenergy 35,11(2011):4497-503.

Garrison, M.V., T.L. Richard, W. Powers-Schilling, and M. Burkart. Final Report for the Iowa Livestock Industry Waste Characterization and Methane Recovery Information Dissemination Project. Des Moines, IA: Iowa Department of Natural Resources, Energy \& Geological Resources Division, 2003.

Hamilton, D.W. Anaerobic Digestion of Animal Manures: Types of Digesters. Stillwater: Oklahoma State University, Oklahoma Cooperative Extension Service Fact Sheet BAE1750, 2013.

Interagency Working Group on Social Cost of Greenhouse Gases. Technical Support Document: Technical Update of the Social Cost of Carbon for Regulatory Impact Analysis under Executive Order 12866. Washington, DC: U.S. Government, May 2013.

Intergovernmental Panel on Climate Change (IPCC). IPCC Second Assessment: Climate Change 1995. IPCC, 1996. Internet site: https://www.ipcc.ch/pdf/ climate-changes-1995/ipcc-2nd-assessment/2nd-assessment-en.pdf (Accessed May 20, 2014).

Kim, W., D. Chattopadhyay, and J.B. Park. "Impact of Carbon Cost on Wholesale Electricity Price: A Note on Price Pass-Through Issues.” Energy 35,8(2010):3441-48.

Kruger, C., S. Chen, C. MacConnell, J. Harrison, R. Shumway, T. Zhang, K. Oakley, et al. "High-Quality Fiber and Fertilizer as Coproducts from Anaerobic Digestion." Journal of Soil and Water Conservation 63,1(2008):12A-13A.

Lashof, D.A., and D.R. Ahuja. "Relative Contributions of Greenhouse Gas Emissions to Global Warming.” Nature 344(April 1990):529-31.

Lazarus, W.F., and M. Rudstrom. "The Economics of Anaerobic Digester Operation on a Minnesota Dairy Farm.” Review of Agricultural Economics 29,2(2007):349-64.

Maaß, O., P. Grundmann, and C. von Bock von Polach. "Added-Value from Innovative Value Chains by Establishing Nutrient Cycles via Struvite." Resources, Conservation and Recycling 87(June 2014):126-36.

McCarl, B.A., A.W. Thayer, and J.P.H. Jones. "The Challenge of Climate Change Adaptation for Agriculture: An Economically Oriented Review." Journal of Agricultural and Applied Economics. 48(November 2016):321-44.

Meinen, R.J., K.B. Kephart, and R.E. Graves. "Economic Feasibility and Evaluation of a Novel Manure Collection and Anaerobic Digestion System at a Commercial Swine Finisher Enterprise." Biomass and Bioenergy 63(April 2014):10-21.

MidWest Plan Service (MWPS). Livestock Waste Facilities Handbook. 2nd ed. Ames: Iowa State University, 1985.

Omri, A., S. Daly, and D.K. Nguyen. "A Robust Analysis of the Relationship between Renewable Energy Consumption and Its Main Drivers." Applied Economics 47,28(2015):2913-23.

Pimentel, D., L.E. Hurd, A.C. Bellottie, M.J. Forster, I.N. Oka, O.D. Sholes, and R.J. Whitman. "Food Production and the Energy Crisis." Science 182,4111(1973):443-49. 
Pimentel, D., and M. Pimentel, eds. Food, Energy, and Society. Rev. ed. Niwot: University Press of Colorado, 1996

Pimentel, D., S. Williamson, C.E. Alexander, O. Gonzalez-Pagan, C. Kontak, and S.E. Mulkey. "Reducing Energy Inputs in the US Food System." Human Ecology 36,4(2008): 459-71.

Ribaudo, M., J. Kaplan, L. Chistensen, N. Gollehon, R. Johansson, V. Breneman, M. Aillery, J. Agapoff, and M. Peters. Manure Management for Water Quality: Costs to Animal Feeding Operations of Applying Manure Nutrients to Land. Washington, DC: U.S. Department of Agriculture, Economic Research Service, Agricultural Economic Report No. 825, June 2003.

RSMeans. 2014 Building Construction Cost Data. 72nd annual ed. Norwell, MA: Reed Construction Data, 2013.

Shu, L. P., Schneider, V. Jegatheesan, and J. Johnson. "An Economic Evaluation of Phosphorus Recovery as Struvite from Digester Supernatant.” Bioresource Technology 97,17(2006):2211-16.

Sommer, S.G., M.L. Christensen, T.S. Schmidt, and L.S. Jensen, eds. Animal Manure Recycling: Treatment and Management. Chichester, West Sussex, UK: John Wiley \& Sons, 2013.

Stokes, J.R., R.M. Rajagopalan, and S.E. Stefanou. "Investment in a Methane Digester: An Application of Capital Budgeting and Real Options." Review of Agricultural Economics 30,4(2008):664-76.

Tchobanoglous, G., H.D. Stensel, R. Tsuchihashi, F. Burton, M. Abu-Orf, G. Bowden, and W. Pfrang. Wastewater Engineering: Treatment and Resource Recovery. 5th ed. New York: McGraw-Hill, 2014.

U.S. Army Corps of Engineers(USACE). Federal Discount Rate for Fiscal Year 2012: Economic Guidance Memorandum 12-01. Washington, DC: Department of the Army, USACE, October 2011.

U.S. Department of Agriculture, Economic Research Service (USDA-ERS). "Average U.S. Farm Prices for Selected Fertilizers, 1960-2013.” Internet site: http://www.ers.usda.gov/ data-products/fertilizer-use-and-price.aspx\#.U5XR6_ldW2E (Accessed June 4, 2014).

U.S. Department of Agriculture, National Agricultural Statistics Service (USDANASS). Overview of the United States Hog Industry. Washington, DC: USDANASS, 2015. Internet site: http://usda.mannlib.cornell.edu/usda/current/hogview/ hogview-10-29-2015.pdf (Accessed September 13, 2018).

U.S. Department of Agriculture, Natural Resources Conservation Service (USDA-NRCS). “Agricultural Waste Characteristics.” Part 651 Agricultural Waste Management Field Handbook. Washington, DC: USDA-NRCS, 210-VI-AWMFH, March 2008.

U.S. Department of Energy (USDOE). "Database of State Incentives for Renewables \& Efficiency." Internet site: http://www.dsireusa.org/ (Accessed 2014).

U.S. Environmental Protection Agency (USEPA). Inventory of U.S. Greenhouse Gas Emissions and Sinks: 1990-2012. Washington, DC: USEPA, EPA 430-R-14-003, $2014 \mathrm{a}$.

- NPDES Permit Writers' Manual for Concentrated Animal Feeding Operations. Washington, DC: USEPA, Office of Wastewater Management, EPA 833-F-12-001, 2012.

—. "AgSTAR Livestock Anaerobic Digester Database." Washington, DC: USEPA, January 2014b. Internet site: https://www.epa.gov/agstar/livestock-anaerobicdigester-database (Accessed 2013).

Uysal, A., Y.D. Yilmazel, and G.N. Demirer. "The Determination of Fertilizer Quality of the Formed Struvite from Effluent of a Sewage Sludge Anaerobic Digester." Journal of Hazardous Materials 181,1-3(2010):248-54. 
Wade, T., L. Kurkalova, and S. Secchi. "Modeling Field-Level Conservation Tillage Adoption with Aggregate Choice Data." 41,2(2016):266-85.

Wang, Q., E. Thompson, R. Parsons, G. Rogers, and D. Dunn. "Economic Feasibility of Converting Cow Manure to Electricity: A Case Study of the CVPS Cow Power Program in Vermont." Journal of Dairy Science 94,10(2011):4937-49.

Wilkinson, K.G. "A Comparison of the Drivers Influencing Adoption of On-Farm Anaerobic Digestion in Germany and Australia." Biomass and Bioenergy 35,5(2011):1613-22.

Yilmazel, Y.D., and G.N. Demirer. "Removal and Recovery of Nutrients as Struvite from Anaerobic Digestion Residues of Poultry Manure.” Environmental Technology 32,7(2011):783-94.

Zaks, D.P.M., N. Winchester, C.J. Kucharik, C.C. Barford, S. Paltsev, and J.M. Reilly. "Contribution of Anaerobic Digesters to Emissions Mitigation and Electricity Generation under U.S. Climate Policy." Environmental Science and Technology 45,16(2011):6735-42.

Zhang, H., and B. Raun. Oklahoma Soil Fertility Handbook. Stillwater: Department of Plant and Soil Sciences, Oklahoma State University, 2006. 